\title{
Asupan mikronutrien sebagai faktor risiko kejadian sindrom pramenstruasi pada wanita vegetarian
}

\author{
Maria Dolorosa Sus Renata, Nurmasari Widyastuti*, Choirun Nissa
}

\begin{abstract}
Background : Inadequate of vitamin B6, magnesium, zinc, and calcium intake and a lower body mass index can lead to Premenstrual syndrome (PMS) in vegetarian woman. The objective of this study was to determine the association between micronutrients intake, nutritional status and PMS among vegetarian women.

Objectives: The objective of this study was to determine the association between micronutrients intake, nutritional status and PMS among vegetarian women.

Methods : A cross sectional study was conducted to 44 vegetarians women.Subjects of this study were collected consecutively. Dietary intake were measured by Semi Quantitative Food Frequency Questionnaire (SQFFQ). Score of PMS were measured by Shortened Premenstrual Assessment Form (sPAF).Physical activity were measured by International Physical Activity Questionnaire (IPAQ). Score of stress level were measured by International Physical Activity Questionnaire (PSS-10). Data were analyzed by Chi Square test and ratio prevalence to determine the risk factor.

Results : There were $54.55 \%$ of subject have a moderate PMS level. There were a correlation between vitamin B6 and PMS $(p=0.019 ; R P=2.96 ; 95 \% C I=0.9-10), \quad$ magnesium and $P M S \quad(p=0.033 ; R P=3.8 ; 95 \% C I=0.6-23), \quad z i n c \quad$ and $P M S$ $(p=0.002 ; R P=6.17 ; 95 \% C I=0.9-39)$, physical activity and $P M S(p=0.033 ; R P=3.79 ; 95 \% C I=0.6-23)$, stress level and $\operatorname{PMS}(p=0.045 ; R P=0.39 ; 95 \% C I=0.1-1.3)$. There were no correlation between calcium intake and PMS $(p=0.211 ; R P=1.816 ; 95 \% ; C I=0.569-5.794), B M I$ and $P M S(p=0.355 ; R P=0.753 ; 95 \% ; C I=1.443)$.

Conclusion : Intake of vitamin B6, magnesium and zinc, physical activity and stress level were correlated to PMS. Calcium intake and BMI were not correlated to PMS.
\end{abstract}

Keywords : micronutrient intake, nutritional status, premenstrual syndrome, vegetarian woman

\section{ABSTRAK}

Latar Belakang : Kekurangan asupan vitamin B6, magnesium, seng, dan kalsium dapat memicu terjadinya sindrom pramenstruasi (premenstrual syndrome atau PMS) pada wanita vegetarian. Vegetarian cenderung memiliki Indeks Massa Tubuh (IMT) yang rendah.

Tujuan : Mengetahui hubungan asupan mikronutrien (vitamin B6, magnesium, seng, kalsium) dan status gizi dengan PMS pada wanita vegetarian.

Metode : Penelitian cross sectional dilakukan pada 44 wanita vegetarian yang dipilih secara konsekutif. Instrumen yang digunakan adalah Semi-quantitative Food Frequency Questionaire (SFFQ) untuk mengukur asupan makan; Shortened Premenstrual Assessment Form (sPAF) untuk mengukur intensitas gejala PMS; International Physical Activity Questionaire (IPAQ) untuk mengukur aktivitas fisik dan International Physical Activity Questionaire (PSS-10) untuk mengukur tingkat stres. Data dianalisis dengan uji Chi Square dan dihitung rasio prevalensi untuk menentukan besar risiko.

Hasil : Ada hubungan antara asupan vitamin B6 dan PMS ( $p=0,019 ; R P=2,96 ; 95$ CI=0,9-10), magnesium dan PMS $(p=0,033 ; R P=3,8 ; 95 \% ; C I=0,6-23)$, seng dan PMS $(p=0,002 ; R P=6,17 ; 95 \% ; C I=0,9-39)$, aktivitas fisik dan PMS $(p=0,033 ; R P=3,79 ; 95 \% ; C I=0,6-23)$, tingkat stres dan $P M S(p=0,045 ; R P=0,39 ; 95 \% ; C I=0,1-1,3)$. Tidak ada hubungan antara asupan kalsium dan PMS $(p=0,211 ; R P=1,816 ; 95 \% ; C I=0,569-5,794), I M T$ dan PMS $(p=0,355 ; R P=0,753 ; 95 \%$; $C I=0,393$ 1,443).

Simpulan : Asupan vitamin B6, asupan magnesium, asupan seng, aktivitas fisik dan tingkat stress berhubungan dengan risiko terjadinya PMS. Asupan kalsium dan IMT tidak berhubungan dengan PMS.

Kata Kunci : asupan mikronutrien, status gizi, sindrom pramenstruasi, wanita vegetarian

\section{PENDAHULUAN}

Sindrom pramenstruasi (Premenstrual syndrome atau PMS) adalah sekumpulan gejala pada wanita usia subur akibat dari perubahan hormonal yang berkaitan dengan siklus ovulasi atau saat terjadinya pelepasan sel

Departemen Ilmu Gizi, Fakultas Kedokteran, Universitas Diponegoro. Jl. Prof. H. Soedarto, Tembalang, Semarang 50275

*Korespondensi : widyastutianlene@gmail.com telur dari ovarium. PMS muncul secara siklik dalam rentang waktu $7-10$ hari sebelum menstruasi dimulai dan menghilang 4 hari setelah haid keluar. ${ }^{1}$ Gejala yang sering dialami seperti nyeri di perut dan payudara, perut kembung, perubahan nafsu makan, depresi, dan cemas. ${ }^{2}$ Sebuah studi epidemiologi menunjukkan bahwa kurang lebih 20\% dari wanita usia reproduksi mengalami PMS. $^{3}$ PMS menyebabkan terjadinya Premenstrual Dysphoric Disorder (PMDD) yang merupakan suatu sprektrum klinis lanjutan PMS dengan derajat yang lebih berat dari PMS yang 
mengakibatkan penurunan produktivitas berkaitan dengan menurunnya kemampuan koordinasi, sukar berkonsentrasi, dan labilitas emosi. ${ }^{2}$ Sekitar 3-8\% wanita usia reproduksi mengalami PMDD. Wanita yang mengalami PMDD biasanya memiliki gejala depresi berat, lekas marah, dan ketegangan sebelum menstruasi. ${ }^{3}$ PMS disebabkan karena adanya ketidakseimbangan antara estrogen dan progesteron dalam fase luteal. ${ }^{4}$ Defisiensi pada fase luteal, terutama mikronutrien (vitamin B6, magnesium, seng, dan kalsium) dapat memicu terjadinya PMS. ${ }^{3}$

Pola hidup vegetarian telah menjadi gaya hidup masyarakat modern sehingga beberapa orang telah memilih untuk melakukan diet vegetarian. Perbedaan antara pola makan vegetarian dan non vegetarian terletak pada ada tidaknya konsumsi bahan makanan hewani dan proporsi konsumsi bahan makanan nabati. ${ }^{5,6}$ Terdapat tiga jenis vegetarian, yaitu vegan (vegetarian yang sama sekali tidak mengonsumsi makanan hewani beserta olahannya), lakto-vegetarian (vegetarian yang masih diperbolehkan mengonsumsi susu beserta olahannya, dan lakto-ovo vegetarian (vegetarian yang masih diperbolehkan mengonsumsi telur dan susu beserta produk olahannya). ${ }^{7}$ Perbedaan pola makan tersebut mempengaruhi jumlah asupan makanan dan zat-zat gizi yang dapat memberikan pengaruh yang berbeda terhadap status gizi dan kesehatan pada vegetarian dan nonvegetarian. ${ }^{6}$ Kaum vegetarian berisiko mengalami defisiensi beberapa unsur penting dalam tubuh, seperti vitamin B6, magnesium, seng dan kalsium, karena zat- zat gizi tersebut banyak dijumpai di dalam bahan makanan hewani, sementara kaum vegetarian bukanlah pemakan hewani. $^{8}$

Penelitian yang dilakukan pada wanita vegetarian usia 12-21 tahun sebanyak 50\% dari 22 orang memiliki asupan magnesium kurang dan 54,5\% memiliki asupan vitamin B6 kurang. ${ }^{9}$ Sementara itu, hasil penelitian di Yayasan Sri Sathya Sai Bali Tahun 2011 menunjukkan bahwa sebagian besar subjek yang vegetarian memiliki asupan energi, protein, kalsium, zat besi, seng dan vitamin $C$ yang kurang. ${ }^{6}$ Sementara itu, penelitian pada kelompok vegan usia 21-45 tahun di Sai Study Group Denpasar (2015) menunjukkan bahwa semua subjek memiliki asupan seng yang kurang. ${ }^{10}$ Hasil pemeriksaan kadar kalsium darah pada vegetarian di Surabaya Tahun 2016 menunjukkan bahwa sebanyak $84 \%$ dari 25 orang mempunyai kadar kalsium darah di bawah normal. ${ }^{8}$

Saat fase luteal, wanita usia reproduksi membutuhkan asupan mikronutrien seperti magnesium, vitamin B6, seng, dan kalsium untuk mengurangi gejala PMS. Mikronutrien dapat diperoleh dari berbagai sumber makanan, akan tetapi tidak semua sumber makanan yang mengandung mikronutrien dapat dikonsumsi oleh wanita vegetarian, seperti daging, ikan yang kaya kandungan seng dan vitamin B6. ${ }^{10}$ Penelitian yang dilakukan pada wanita vegetarian di Semarang menunjukkan bahwa sebesar $31,7 \%$ mengalami PMS. ${ }^{9}$

Magnesium, vitamin B6, seng dan kalsium dapat membantu menurunkan risiko terjadinya PMS. Magnesium bersama dengan vitamin B6 memiliki peran penting yang membantu sintesis konjugasi hormon estrogen. Magnesium berperan dalam meningkatkan aktivitas enzim glucuronyl transferase yang akan mengaktivasi vitamin B6 ke bentuk aktifnya yaitu pyridoxal phosphate. ${ }^{11}$ Asupan magnesium rendah memicu terjadinya penurunan kadar magnesium dalam darah yang akan berpengaruh terhadap jalannya proses aktivasi enzim dan vitamin B6. ${ }^{2,11}$

Seng berperan dalam menghambat peningkatan produksi hormon prostaglandin yang menyebabkan perut kembung dan terasa nyeri saat PMS. ${ }^{12}$ Asupan seng yang adekuat dapat menurunkan terjadinya nyeri perut. Tidak semua sumber seng dapat dikonsumsi oleh kelompok vegetarian, hanya gandum, coklat, dan golongan biji-bijian saja yang dapat dikonsumsi. ${ }^{13}$ Sementara itu, kalsium berperan dalam sintesis neurotransmitter (serotonin) saat terjadi PMS. Kurangnya asupan kalsium mengakibatkan sintesis serotonin terganggu dan terjadi perubahan kalsium pada ekstraseluler sehingga dapat meningkatan emosi dan perubahan mood saat PMS. ${ }^{11}$

Faktor lain yang juga dapat berkontribusi terhadap terjadinya sindrom pramenstruasi adalah status gizi. Vegetarian berisiko memiliki Indeks Massa Tubuh (IMT) lebih rendah daripada nonvegetarian. ${ }^{5}$ Wanita dengan IMT rendah berisiko 1,3 kali mengalami nyeri seperti yang dinyatakan dalam penelitian pada wanita usia 18-21 tahun di Jepang. ${ }^{14}$ IMT rendah berkaitan ketidakcukupan zat gizi dalam tubuh sehingga simpanan zat gizi dalam jaringan berkurang karena digunakan tubuh untuk memenuhi ketidakcukupan tersebut. Hal ini menyebabkan kondisi fisik lemah sehingga ketahanan terhadap rasa nyeri berkurang. ${ }^{15}$

Selain status gizi, faktor stress dan kurang aktivitas fisik juga dapat memengaruhi terjadinya PMS. Saat stres terjadi ketidakseimbangan hormon adrenalin, estrogen, progesteron dan prostaglandin yang menyebabkan perut terasa nyeri saat PMS. $^{4}$ Kurang aktivitas fisik dapat menekan produksi endorfin yang merupakan analgesik alami yang membantu meredakan nyeri bila terjadi PMS. ${ }^{16}$

Tingkat keparahan PMS berkaitan erat dengan perubahan asupan zat gizi dan status gizi pada wanita vegetarian. Hal ini akan berdampak pada kualitas hidup dan produktivitas kerja wanita vegetarian. Berdasarkan latar belakang tersebut, maka tujuan dari penelitian ini adalah untuk mengetahui hubungan asupan 
mikronutrien (vitamin B6, magnesium, seng, kalsium) dan status gizi dengan PMS pada wanita vegetarian.

\section{BAHAN DAN METODE}

Penelitian ini merupakan penelitian deskriptif analitik dengan metode cross sectional, termasuk dalam ruang lingkup ilmu gizi masyarakat, dan dilakukan di Indonesian Vegetarian Society (IVS) cabang Yogyakarta pada Desember 2016. Populasi dalam penelitian ini adalah semua wanita yang tergabung dalam IVS cabang Yogyakarta. Pemilihan subjek dilakukan dengan metode consecutive sampling, dengan kriteria inklusi usia 19-25 tahun, menjalani vegetarian minimal 6 bulan, tidak sedang mengalami menstruasi, dan dapat berkomunikasi dengan baik; dan bersedia mengikuti penelitian dengan mengisi formulir informed consent. Penelitian ini dilengkapi dengan ethical clearance yang ditandatangani oleh Komisi Etik Fakultas Kedokteran Universitas Diponegoro/Rumah Sakit Umum Pusat Dr. Kariadi Semarang. Berdasarkan perhitungan dengan rumus analitik korelatif dibutuhkan sampel minimal sebanyak 40 subjek. Namun, berdasarkan kriteria insklusi terdapat 44 subjek yang berpartisipasi dalam penelitian ini.

Variabel bebas dalam penelitian ini adalah asupan zat gizi mikro (vitamin B6, magnesium, seng, kalsium) dan status gizi yang diukur dengan IMT sedangkan variabel terikat dalam penelitian ini adalah sindrom pramenstruasi (PMS). Aktivitas fisik dan faktor stres sebagai variabel perancu dalam penelitian ini. Data yang diambil dalam penelitian ini antara lain data identitas subjek, data antropometri (tinggi badan dan berat badan), data asupan vitamin B6, magnesium, seng, dan kalsium, data intensitas gejala PMS, data aktivitas fisik, dan data tingkat stres. Pengukuran antropometri meliputi pengukuran tinggi badan dengan menggunakan microtoise dengan ketelitian $0,1 \mathrm{~cm}$, serta pengukuran berat badan menggunakan timbangan injak digital dengan ketelitian $0,1 \mathrm{~kg}$.

Data intensitas gejala PMS pada siklus menstruasi terakhir diukur menggunakan shortened Premenstrual Assessment Form (sPAF) terdiri dari 10 pertanyaan kemudian diisi sesuai dengan kondisi yang dialami dengan kriteria ringan, sedang, dan berat. Total skor diperoleh dari penjumlahan seluruh skor tiap kriteria yang dipilih. Hasil perhitungan dikategorikan menjadi PMS ringan (11-30), untuk PMS sedang ( 3149), dan PMS berat $(\geq 50) \cdot{ }^{17}$ Data asupan makanan diperoleh melalui wawancara langsung menggunakan Semi-quantitative Food Frequency Questionare (SQFFQ) oleh enumerator terlatih. Data diolah dan dianalisis menggunakan software kemudian dibandingkan dengan Angka Kecukupan Gizi (AKG) dan dikategorikan menjadi tiga yaitu kurang $(<80 \%)$, cukup $(80-110 \%)$ dan lebih (>110\%). ${ }^{18}$ Aktivitas fisik diukur menggunakan International Physical Activity Questionaire (IPAQ) untuk mengetahui besar energi yang dikeluarkan subjek dalam beraktivitas selama 7 hari terakhir kemudian diberikan skor dan dihitung menggunakan rumus yang sudah ditentukan dengan satuan MET-menit/minggu. Hasil perhitungan dikategorikan menjadi aktivitas ringan (<600 METmenit/minggu), aktivitas sedang (600-2999 METmenit/minggu) dan aktivitas berat (>2999 METmenit/minggu). ${ }^{19}$ Data yang menggambarkan tingkat stres dapat diperoleh melalui Perceived Stress Scale 10 (PSS-10) untuk mengetahui keadaaan yang dialami selama 1 bulan terakhir dengan memberikan skor sesuai dengan kriteria, kemudian total skor yang diperoleh dikategorikan menjadi stres ringan (0-13), stres sedang (14-26), stres tinggi (27-40). ${ }^{20}$

Penelitian ini menggunakan analisis univariat dan analisis bivariat. Analisis univariat untuk mendeskripsikan masing-masing variabel dalam penelitian. Analisis bivariat menggunakan uji Chi Square untuk mengetahui hubungan antar variabel dan perhitungan rasio prevalensi untuk menentukan besar risiko.

\section{HASIL}

Karakteristik subjek ditunjukkan pada Tabel 1. Pada penelitian ini didapatkan sebanyak 44 wanita yang memenuhi kriteria inklusi dengan rerata usia $21,61 \pm 2,03$ tahun dan rentang usia 19-25 tahun, terdiri dari 23 orang lacto-ovovegetarian, 4 subjek lacto vegetarian dan 17 orang vegan. IMT terendah dari 44 subjek adalah $17 \mathrm{~kg} / \mathrm{m}^{2}$ yang dimiliki oleh seorang vegan. Rata-rata subjek telah menjalani diet vegetarian selama lebih dari lima tahun, bahkan sejak usia dini telah diajarkan oleh keluarga untuk menjadi seorang vegetarian.

Hasil penelitian ini menunjukkan bahwa 24 subjek $(54,55 \%)$ mengalami PMS tingkat sedang, 19 subjek $(43,18 \%)$ mengalami PMS ringan, dan 1 subjek $(2,27 \%)$ mengalami PMS berat. Tabel 2 menunjukkan distribusi frekuensi asupan mikronutrien, IMT dan aktivitas fisik menurut intensitas PMS. Sebanyak 23 subjek (52,3 \%) dengan asupan vitamin B6 yang kurang, mengalami PMS sedang-berat. Sebanyak 24 subjek $(54,5 \%)$ yang kekurangan asupan magnesium mengalami PMS sedang-berat. PMS sedang-berat juga dialami oleh subjek yang kekurangan asupan seng, yaitu sebanyak 24 subjek $(54,5 \%)$ dan subjek yang kekurangan asupan kalsium, yaitu sebanyak 23 subjek $(52,3 \%)$. 
Tabel 1. Nilai Minimum, Maksimum, Rerata dan Standar Deviasi Karakteristik Subjek

\begin{tabular}{lccc}
\hline \multicolumn{1}{c}{ Karakteristik Subjek } & \multicolumn{1}{c}{$\mathbf{n}=\mathbf{4 4}$} \\
\cline { 2 - 4 } & Minimum & Maksimum & Rerata \pm SD \\
\hline Usia responden (tahun) & 19 & 25 & $21,61 \pm 2,03$ \\
Berat badan (kg) & 40 & 65,4 & $47,99 \pm 5,41$ \\
Tinggi badan (cm) & 144 & 163 & $156,0 \pm 4,51$ \\
Indeks Massa Tubuh (kg/m ${ }^{2}$ ) & 17,0 & 26,6 & $19,62 \pm 1,95$ \\
Skor Intensitas gejala PMS & 13 & 50 & $31,43 \pm 9,91$ \\
Asupan & & & \\
$\quad$ Asupan vitamin B6 (mg) & 0,5 & 2,4 & $1,10 \pm 0,44$ \\
$\quad$ Asupan magnesium (mg) & 101 & 738 & $234,11 \pm 115,62$ \\
$\quad$ Asupan seng (mg) & 2,3 & 15,3 & $7,80 \pm 2,87$ \\
$\quad$ Asupan kalsium (mg) & 0,3 & 1583,1 & $574,90 \pm 3,93$ \\
Skor Aktifitas fisik (MET- & 99 & 2415 & $478,43 \pm 478,37$ \\
menit/minggu) & & & \\
Skor Tingkat stres & 0 & 26 & $16,70 \pm 5,73$ \\
\hline
\end{tabular}

Tabel 2. Distribusi Frekuensi Asupan Mikronutrien Menurut Intensitas PMS

\begin{tabular}{lrrr}
\hline Karakteristik dan Kategori & PMS & Sedang+Berat & Total \\
\hline & Ringan & n (\%) & n (\%) \\
\hline Asupan Vitamin B6 & n (\%) & & \\
Kurang & & & $35(79,6 \%)$ \\
Cukup & $12(27,3 \%)$ & $23(52,3 \%)$ & $2(4,5 \%)$ \\
Lebih & $2(4,5 \%)$ & $0(0,0 \%)$ & $7(15,9 \%)$ \\
Asupan Magnesium & $5(11,3 \%)$ & $2(4,5 \%)$ & $38(86,4 \%)$ \\
Kurang & & $24(54,5 \%)$ & $1(2,3 \%)$ \\
Cukup & $14(31,8 \%)$ & $0(0,0 \%)$ & $5(11,3 \%)$ \\
Lebih & $1(2,3 \%)$ & $1(2,3 \%)$ & $35(79,6 \%)$ \\
Asupan Seng & $4(9,0 \%)$ & $24(54,5 \%)$ & $3(6,8 \%)$ \\
Kurang & & $0(0,0 \%)$ & $6(13,6 \%)$ \\
Cukup & $11(25,0 \%)$ & $1(2,3 \%)$ & $38(86,4 \%)$ \\
Lebih & $3(6,8 \%)$ & $6(13,6 \%)$ \\
Asupan Kalsium & $5(11,3 \%)$ & $23(52,3 \%)$ & $6(13,6 \%)$ \\
Kurang & & $2(4,5 \%)$ & \\
Lebih & $15(34,1 \%)$ & $1(2,3 \%)$ & \\
Sedang & $4(9,0 \%)$ & & \\
\hline
\end{tabular}

Tabel 3. Distribusi Frekuensi IMT, Aktivitas Fisik dan Tingkat Stres Menurut Intensitas PMS

\begin{tabular}{llrr}
\hline Karakteristik dan Kategori & PMS & Sedang+Berat & Total \\
\cline { 2 - 4 } & Ringan & n $(\%)$ & n (\%) \\
\cline { 2 - 4 } & $\mathbf{n}(\%)$ & $6(13,6 \%)$ & $12(27,2 \%)$ \\
Status Gizi & $6(13,6 \%)$ & $19(4,3 \%)$ & $31(70,5 \%)$ \\
Underweight & $12(27,2 \%)$ & $0(0,0 \%)$ & $1(2,3 \%)$ \\
Normal & $1(2,3 \%)$ & $24(54,5 \%)$ & $38(86,4 \%)$ \\
Overweight & & $1(2,3 \%)$ & $6(13,6 \%)$ \\
Aktivitas Fisik & $14(31,8 \%)$ & & \\
Ringan & $5(11,3 \%)$ & $23(52,3 \%)$ & $36(81,9 \%)$ \\
Sedang & & $2(4,5 \%)$ & $8(18,1 \%)$ \\
Tingkat Stres & $13(29,6 \%)$ & & \\
Sedang & $6(13,6 \%)$ & & \\
Rendah & & & \\
\hline
\end{tabular}

Tabel 3 menunjukkan bahwa pada subjek yang tergolong PMS ringan, sebagian besar mempunyai status gizi normal, yaitu sebanyak 12 subjek $(27,2 \%)$. Sementara itu, sebanyak 24 subjek $(54,5 \%)$ yang memiliki aktivitas fisik tergolong ringan, mengalami PMS sedang- berat.
Asupan vitamin B6, magnesium dan seng merupakan faktor risiko kejadian PMS pada wanita vegetarian sedangkan asupan kalsium dan status gizi bukan merupakan faktor risiko Kejadian PMS pada wanita vegetarian. Wanita vegetarian yang kekurangan asupan vitamin B6 berisiko 2,96 kali lebih besar 
mengalami PMS dibandingkan wanita vegetarian dengan asupan vitamin B6 yang cukup. Wanita vegetarian yang kekurangan asupan magnesium memiliki risiko 3,79 kali lebih besar mengalami PMS dibandingkan wanita vegetarian dengan asupan magnesium yang cukup. Vegetarian yang kekurangan asupan seng memiliki risiko 6,17 kali lebih besar mengalami PMS dibandingkan vegetarian dengan asupan seng cukup. Aktivitas fisik diketahui berhubungan dengan PMS $(p=0,033)$ (Tabel 4).

Tabel 4 juga menunjukkan aktivitas fisik sebagai faktor risiko kejadian PMS pada wanita vegetarian. Vegetarian dengan aktivitas fisik yang tergolong ringan, memiliki risiko 3,79 kali lebih besar mengalami PMS dibandingkan vegetarian dengan aktivitas yang sedang. Subjek dengan tingkat stres rendah memiliki risiko 0,39 kali mengalami PMS sehingga merupakan faktor protektif terjadinya PMS.

Tabel 4. Besar Risiko Asupan Mikronutrien, Status Gizi, Aktivitas Fisik, dan Tingkat Stres dengan Sindrom Pramenstruasi

\begin{tabular}{|c|c|c|c|c|c|c|}
\hline \multirow[t]{3}{*}{ Variabel } & \multicolumn{2}{|c|}{ PMS } & \multirow[t]{3}{*}{$p$} & \multirow{3}{*}{$\mathbf{R} \mathbf{P}^{\mathbf{a}}$} & \multicolumn{2}{|c|}{$95 \%$ CI } \\
\hline & \multirow{2}{*}{$\begin{array}{l}\text { Ringan } \\
\mathbf{n}(\%) \\
\end{array}$} & \multirow{2}{*}{$\begin{array}{l}\text { Sedang+berat } \\
\mathrm{n}(\%)\end{array}$} & & & & \\
\hline & & & & & Lower & Upper \\
\hline Asupan Vitamin B6 & & & & & & \\
\hline Kurang & $12(27,3 \%)$ & $23(52,3 \%)$ & $0,019^{\mathrm{b}}$ & 2,96 & 0,851 & 10,275 \\
\hline Cukup + lebih & $7(15,9 \%)$ & $2(4,5 \%)$ & & & & \\
\hline Asupan Magnesium & & & & & & \\
\hline Kurang & $14(31,8 \%)$ & $24(54,5 \%)$ & $0,033^{b}$ & 3,79 & 0,623 & 23,054 \\
\hline Cukup+lebih & $5(11,4 \%)$ & $1(2,3 \%)$ & & & & \\
\hline Asupan Seng & & & & & & \\
\hline Kurang & $11(25,0 \%)$ & $24(54,5 \%)$ & $0,002^{\mathrm{b}}$ & 6,17 & 0,959 & 39,701 \\
\hline Cukup+lebih & $8(18,2 \%)$ & $1(2,3 \%)$ & & & & \\
\hline Asupan Kalsium & & & & & & \\
\hline Kurang & $15(34,1 \%)$ & $23(52,3 \%)$ & 0,211 & 1,82 & 0,569 & 5,794 \\
\hline Cukup & $4(9,1 \%)$ & $2(4,5 \%)$ & & & & \\
\hline IMT & & & & & & \\
\hline Underweight+overweight & $7(15,9 \%)$ & $6(13,6 \%)$ & 0,355 & 0,75 & 0,393 & 1,443 \\
\hline Normal & $12(27,3 \%)$ & $19(43,2 \%)$ & & & & \\
\hline Aktivitas Fisik & & & & & & \\
\hline Ringan & $14(31,8 \%)$ & $24(54,5 \%)$ & $0,033^{\mathrm{a}}$ & 3,79 & 0,623 & 23,054 \\
\hline Sedang & $5(11,4 \%)$ & $1(2,3 \%)$ & & & & \\
\hline Tingkat Stres & & & & & & \\
\hline Rendah & $6(13,6 \%)$ & $2(4,5 \%)$ & $0,045^{\mathrm{a}}$ & 0,39 & 0,115 & 1,332 \\
\hline Sedang & $13(29,6 \%)$ & $23(52,3 \%)$ & & & & \\
\hline
\end{tabular}

${ }^{a}$ Rasio Prevalensi

${ }^{\mathrm{b}}$ uji Chi Square $(p=<0,05)$

\section{PEMBAHASAN}

Penelitian ini dilakukan pada 44 subjek wanita vegetarian yang terdiri dari 23 orang lactoovovegetarian, 4 orang lacto vegetarian, dan 17 orang vegan dengan rentang usia 19-25 tahun. PMS umum terjadi pada wanita dalam masa reproduksi (sekitar usia 15-46 tahun $)^{21}$ dimana usia 15-46 tahun ini merupakan usia produktif. Wanita pada rentang usia tersebut umumnya memiliki kesibukan yang tinggi, cenderung mudah mengalami stres dan memiliki pola makan yang tidak baik sehingga menyebabkan kekurangan zat gizi tertentu. Kondisi - kondisi tersebut dapat menyebabkan seseorang rentan untuk mengalami PMS. ${ }^{22}$

Hasil penelitian menunjukkan bahwa dari 44 subjek sebanyak 19 subjek $(43,18 \%)$ mengalami PMS ringan, 24 subjek $(54,55 \%)$ mengalami PMS sedang dan 1 subjek $(2,27 \%)$ mengalami PMS berat. Prevalesi ini lebih tinggi jika dibandingkan dengan prevalensi PMS yang dijumpai pada wanita vegetarian usia 18-21 tahun di Jakarta. Pada penelitian tersebut menunjukkan bahwa 3 dari 22 subjek mengalami PMS ringan, 3 subjek mengalami PMS sedang, dan 1 subjek mengalami PMS berat. ${ }^{9}$ Subjek dengan PMS sedang memiliki gejala payudara terasa nyeri dengan skor 4 atau kategori sedang, merasa cemas (skor 4 atau dalam kategori sedang), perut terasa kembung (skor 5 atau berat), dan merasa mudah tersinggung atau sensitif (skor 5 atau dalam kategori berat).

Hasil penelitian ini menyebutkan sebanyak 79,54\% wanita vegetarian memiliki asupan vitamin B6 yang tergolong kurang. Wanita dengan asupan vitamin B6 kurang memiliki risiko 2,957 kali mengalami PMS. Dari analisis bivariat menunjukkan adanya hubungan antara vitamin B6 dengan risiko terjadi PMS pada 
wanita vegetarian. Dalam penelitian yang dilakukan pada mahasiswi di Magelang menunjukkan bahwa asupan vitamin B6 berpengaruh terhadap berkurangnya gejala psikologi PMS. ${ }^{23}$

Kadar vitamin B6 yang rendah dalam darah akan menyebabkan biosintesis serotonin akan terganggu, sehingga memicu timbulnya ovulasi terlalu awal dan terjadi pergantian pola estrogen dan progesteron. Menurunnya kadar serotonin terjadi akibat fluktuasi esterogen yang memicu timbulnya gejala-gejala $\mathrm{PMS}^{24}$ Serotonin memiliki pengaruh dalam memperbaiki mood seseorang dimana vitamin B6 berperan sebagai koenzim dan metabolisme asam amino triptofan yang berkaitan dengan serotonin. Serotonin disintesis dari asam amino triptofan dengan bantuan vitamin B6, maka diperlukan asupan yang cukup untuk mengurangi perasaan emosional yang merupakan salah satu gejala psikologis dari PMS. ${ }^{24}$

Hasil wawancara melalui Semi-quantitative Food Frequency Questionaire (SFFQ) menunjukkan bahwa subjek yang memiliki asupan vitamin B6 yang kurang diketahui jarang mengonsumsi kacangkacangan. Frekuensi konsumsi kacang-kacangan hanya sekitar 1-2x dalam seminggu. Kebutuhan vitamin B6 untuk wanita vegetarian adalah $1,3 \mathrm{mg} /$ hari atau setara dengan $100 \mathrm{~g}$ tempe kedelai (4 potong sedang), $100 \mathrm{~g}$ kacang hijau, $100 \mathrm{~g}$ kacang merah, dan $100 \mathrm{~g}$ kacang tanah. ${ }^{13}$

Hasil analisis bivariat menunjukkan adanya hubungan asupan magnesium dengan PMS. Dalam penelitian ini sebanyak $86,36 \%$ wanita vegetarian memiliki asupan magnesium kurang. Subjek dengan asupan magnesium kurang memiliki risiko 3,79 kali mengalami PMS. Walaupun sebagian besar vegetarian mengonsumsi jenis-jenis sayuran hijau, sayur yang dikonsumsi kurang variatif. Rata-rata vegetarian hanya mengonsumsi sawi dan bayam setiap harinya, jarang mengonsumsi jenis biji-bijian dan kacang-kacangan yang kaya akan magnesium. Frekuensi konsumsi sayuran tersebut juga hanya $1-2 x$ dalam seminggu. Kebutuhan magnesium untuk vegetarian adalah sebesar $310 \mathrm{mg} / \mathrm{hari}$. Subjek dapat mengonsumsi $100 \mathrm{~g}$ bayam, 4 potong sedang tempe, 3 iris roti gandum, 1 buah alpukat, $2 \mathrm{sdm}$ selai kacang tanah, dan $100 \mathrm{~g}$ brokoli untuk memenuhi kebutuhan harian magnesium. ${ }^{13}$

Magnesium merupakan mineral penting yang berfungsi meningkatkan aktivitas enzim glucoronyl transferase yang akan mengaktivasi vitamin B6 menjadi pyridoxal phosphate. ${ }^{11}$ Konsumsi magnesium selama fase luteal sampai saat darah menstruasi keluar, terbukti dapat mengurangi gejala-gejala PMS. Hal ini sejalan dengan penelitian yang dilakukan pada mahasiswi di Padang tahun 2011 yang menyatakan adanya pengaruh signifikan antara tingkat konsumsi magnesium dengan kejadian PMS pada wanita. ${ }^{25}$
Hasil dari penelitian menunjukkan sebanyak 79,54\% wanita vegetarian memiliki asupan seng kurang. Wanita dengan asupan seng kurang memiliki risiko 6,171 kali mengalami PMS. Dari hasil analisis bivariat menunjukkan adanya hubungan antara asupan seng dengan PMS. Kebutuhan seng untuk vegetarian adalah $8 \mathrm{mg} /$ hari. $^{13}$ Wanita vegetarian dapat mengonsumsi bayam 2-3 porsi, $100 \mathrm{~g}$ coklat hitam, 100 $\mathrm{g}$ jamur putih, dan $100 \mathrm{~g}$ beras merah untuk memenuhi kebutuhan seng tersebut. ${ }^{13}$ Seng dapat menghambat produksi prostaglandin yang berlebihan pada jaringan uterus. Prostaglandin merupakan komponen mirip hormon yang berfungsi sebagai respon fisiologis, seperti inflamasi. Kadar prostaglandin yang terlalu tinggi dalam tubuh akan menstimulasi otot polos di uterus sehingga menyebabkan perut terasa kembung dan nyeri pada saat sebelum dan saat menstruasi berlangsung. ${ }^{12}$

Hasil penelitian menunjukkan tidak ada hubungan antara kalsium dengan PMS. Walaupun secara statistik tidak memiliki hubungan, sebanyak $86,36 \%$ wanita vegetarian memiliki asupan kalsium yang kurang dan memiliki risiko 1,82 kali mengalami PMS. Kebutuhan kalsium pada wanita vegetarian adalah $1000 \mathrm{mg} / \mathrm{hari}$. Vegetarian yang menganut jenis lacto dan lacto-ovo vegetarian tentunya masih dapat mengonsumsi sumber kalsium dari produk susu, namun untuk vegan dapat memperoleh kalsium dari sumber nabati seperti kacang-kacangan, sayuran hijau, tahu, susu kedelai. ${ }^{13}$ Peran kalsium adalah untuk mengurangi rasa nyeri yang merupakan salah satu gejala dari PMS. Pada saat otot berkontraksi, kalsium berperan dalam interaksi protein di dalam otot yaitu aktin dan miosin. Apabila otot kekurangan kalsium, maka otot tidak dapat mengendur setelah kontraksi sehingga otot menjadi kram dan timbul rasa nyeri. ${ }^{12}$

Sebagian besar $(70,46 \%)$ wanita vegetarian dalam penelitian ini memiliki IMT normal, 27,2 \% memiliki IMT rendah (underweight), dan sisanya ( 2,3 $\%)$ memiliki IMT overweight. Salah satu wanita vegetarian yang memiliki IMT terendah (IMT 17 $\mathrm{kg} / \mathrm{m}^{2}$ ) dalam penelitian ini adalah seorang vegan. Dalam penelitian pada wanita usia 18-21 tahun di Jepang menyatakan bahwa wanita dengan IMT lebih rendah berisiko mengalami nyeri, ${ }^{14}$ namun hal tersebut bertentangan dengan penelitian ini karena hanya $13,60 \%$ subjek dengan IMT rendah yang tergolong PMS sedang-berat. Sementara itu, pada subjek yang tergolong PMS ringan, sebagian besar mempunyai IMT normal, yaitu sebanyak $27,2 \%$ subjek. Wanita dengan status gizi kurang (underweight) berisiko mengalami Kekurangan Energi Kronis (KEK). Gizi kurang atau terbatas, selain akan memengaruhi pertumbuhan fungsi organ tubuh, penurunan kondisi fisik lemah dan mudah letih, juga dapat menyebabkan terganggunya fungsi reproduksi. Keluhan yang sering 
dirasakan antara nyeri saat haid dan tidak nyaman pada perut. ${ }^{26}$ Konsumsi makanan seimbang sangat dibutuhkan pada saat haid terutama pada fase luteal akan terjadi peningkatan kebutuhan zat gizi. Pada fase luteal terjadi pembentukan dan pemeliharaan korpus luteum sehingga dibutuhkan peningkatan asupan energi. Apabila hal ini diabaikan, dampak yang terjadi ialah timbulnya gejala PMS seperti nyeri perut, mudah letih, sehingga menimbulkan rasa ketidaknyamanan selama siklus haid. ${ }^{26}$

Aktivitas fisik pada penelitian ini diketahui berhubungan dengan PMS. Aktivitas fisik teratur dan berkelanjutan dapat berkontribusi dalam peningkatan dan pelepasan endorfin. Endorfin merupakan hormon yang diproduksi oleh tubuh ketika merasa bahagia. Endorfin berperan dalam sistem kekebalan tubuh dan pengendali stres. PMS terjadi karena adanya ketidakseimbangan estrogen di dalam tubuh. Adanya ketidakseimbangan estrogen ini dapat dicegah dengan meningkatkan produksi endorfin dalam tubuh. Endorfin juga dapat ditemukan dalam sumber makanan seperti coklat hitam, cabai, dan ginseng. Akan tetapi, olahraga dapat meningkatkan produksi endorfin dengan lebih cepat dan efektif karena endorfin dilepaskan secara langsung dalam aliran darah sehingga dapat memperbaiki suasana hati ( $\operatorname{mood}$ ). Hal ini telah dibuktikan dengan olahraga teratur dapat menurunkan risiko terjadinya PMS dalam penelitian pada 40 orang mahasiswi usia $18-22$ dengan nilai $\mathrm{p}=0,000(<0,05){ }^{27}$

Pada penelitian ini juga dijumpai terdapat hubungan antara tingkat stres dan PMS. Pada keadaan stres, terjadi pengaktifan Hypotalamic Pituitary Axis (HPA) yang mengakibatkan hipotalamus mensekresikan Corticotropic Releasing Hormone (CRH). Hormon ini mempunyai pengaruh negatif terhadap pengaturan sekresi Gonadotropin Releasing Hormone (GnRH). Ketidakseimbangan $\mathrm{CRH}$ memiliki pengaruh terhadap penekanan fungsi reproduksi manusia sewaktu stres. ${ }^{4}$ Sekresi CRH akan merangsang pelepasan Adrenocorticotropic Hormone (ACTH) oleh hipofisis anterior, selanjutnya ACTH akan merangsang kelenjar adrenal untuk sekresi kortisol. Kortisol menekan Luteinizing Hormone (LH) dengan cara menghambat respon hipofisis anterior terhadap GnRH. Selama siklus menstruasi, peran hormon LH sangat dibutuhkan untuk menghasilkan estrogen dan progesteron. Pengaruh hormon kortisol yang menekan LH menyebabkan adanya ketidakseimbangan hormon yang mengakibatkan terjadinya premenstrual syndrome (PMS). ${ }^{28}$

\section{SIMPULAN}

Sebagian besar subjek dengan asupan vitamin B6, magnesium, seng, kalsium yang kurang, mengalami PMS sedang-berat. Subjek dengan PMS ringan sebagian besar mempunyai status gizi baik. Sebagian besar subjek yang kurang aktivitas fisik mengalami PMS sedang-berat. Asupan mikronutrien (vitamin B6, magnesium, dan seng) yang rendah, kurang aktivitas fisik dan tingkat stress yang tinggi meningkatkan risiko terhadap PMS. Asupan kalsium dan status gizi bukan merupakan faktor risiko PMS pada wanita vegetarian.

Wanita vegetarian dianjurkan untuk mengonsumsi asupan mikronutrien (vitamin B6, magnesium, seng, dan kalsium) sesuai kebutuhan serta rutin melakukan aktvitas fisik dan manajemen stres sehingga dapat mengurangi gejala sindrom pramenstruasi. Penelitian lebih lanjut disarankan untuk melakukan pemeriksaan uji laboratorium terkait kadar vitamin B6, magnesium, seng, dan kalsium dalam darah untuk mengetahui status vitamin B6, magnesium, seng dan kalsium dalam tubuh.

\section{DAFTAR PUSTAKA}

1. Dongoes. Kesehatan pediatrik. Jakarta: EGC; 2007. $564 \mathrm{p}$.

2. Suparman, Eddy;Sentosa RI. Premenstrual syndrome. Premenstrual Syndrome. Jakarta: EGC; 2011. 30-1 p.

3. Chocano-Bedoya, Manson J, Hankinson S, Johson S, Chasan-Taber, Ronnenberg A. Intake of selected mineral and risk of premenstrual syndrome. Am J Epid. 2013;1-10.

4. Wiknjosastro, Hanifa. Ilmu kebidanan. 3rd ed. Jakarta: YBP-SP; 2006.

5. Craig W. Health effects of vegan diets. Am J Clin Nutr. 2009;1672S-33S.

6. Meliyani H, Nai E, Adhi KT, Sutiari NK. Kecukupan asupan gizi remaja vegetarian dan nonvegetarian di yayasan sri sathya sai bali tahun 2011. Indones J Public Heal. 2012;1(1):43-9.

7. Susianto, Widjaja H MH. Diet enak ala vegetarian. Jakarta: Penebar Swadaya; 2007. 5 p.

8. Nur S, Yusmiati H, Wulandari RE, Fakultas D, Kesehatan I, Maarif U, et al. Pemeriksaan kadar kalsium pada masyarakat dengan pola makan vegetarian. J SainHealth Ed Maret. 2017;1(1).

9. Setianingsih A, Kartasurya M. Hubungan status vegetarian dengan derajat sindrom pramenstruasi pada remaja. Tidak Dipublikasikan [Skripsi]. Semarang: Universitas Diponegoro; 2012.

10. Sukma, I Wayan Bayu; Dewantari NKA. Pola konsumsi dan status anemia pada vegetarian vegan. J Ilmu Gizi [Internet]. 2015;6(2):121-7. Available from: http://www.poltekkesdenpasar.ac.id/jurnal_category/jurnal-ilmu-gizijig/

11. De-Souza M, Walker A, Robinson P, Bolland K. 
A synergistic effect of a daily supplement for 1 month of $200 \mathrm{mg}$ magnesium plus $50 \mathrm{mg}$ vitamin B6 for the relief of anxiety-related premenstrual symptoms: a randomized, double-blind, crossover study. J Womens Heal Gend Based Med. 2000;9:131.

12. Hollins C, Martin C, RP V. Handbook of diet and nutrition in the menstrual cycle, periconception, and fertility. In: Human Health Handbook vol 7 Netherland: Wagening Academic Publishers; 2014. p. 95-119.

13. Melina V, Craig W, Levin S. Position of the academy of nutrition and dietetics: vegetarian diets. J Acad Nutr Diet. 2015;115:801-10.

14. Hirata M, Kumabe K, Inoue Y. Relationship between the frequency of menstrual pain and bodyweight in female adolescents. Nippon Koshu Eisei Zasshi. 2002; 49(6): 516-24.

15. Sumardilah D. Gizi Tenaga Kerja. In: Hardiansyah, Supariasa IDN, editors. Ilmu gizi teori dan aplikasi. 1st ed. Jakarta; 2016. p. 413-25.

16. Andrew G. Buku ajar kesehatan reproduksi wanita. 2nd ed. Jakarta: EGC; 2009.

17. Lee M, Kim J, Lee J, Kim D. The standardization of the shortened premenstrual assessment form and applicability on the internet. J Korean Neuropsychiatry Assoc. 2002;41:159-67.

18. Widajanti L. Buku petunjuk praktikum survei konsumsi gizi. Semarang: Bagian Prodi Magister Gizi Masyarakat Program Pascasarjana UNDIP; 2007.

19. Ismail S, Sulaiman N, Adnan R. Presents the proceedings 2nd International Colloquium on Sports Science, Exercise, Engineering and
Technology 2015 (ICoSSEET 2015). Springer Science+Business Media Singapore; 2016.

20. Ramesh Bhat M, Sameer MK, Ganaraja B. Eustress in education: analysis of the perceived stress score (PSS) and blood pressure (BP) during examinations in medical students. $\mathbf{J}$ Clin Diagnostic Res. 2012;5(7):1331-5.

21. Mishell DR. Premenstrual disorders: Epidemiology and disease burden. American Journal of Managed Care. 2005; 11.

22. Nurazizah E, Tih Fen SW. Black chocolate consumption reduces subjective symptoms in 1822 years old females with premenstrual syndrome. J Med Heal. 2015; 1: 76-84.

23. Anityo NN\& TW. pengaruh pemberian vitamin bkompleks terhadap kejadian sindroma premenstruasi pada mahasiswa prodi kebidanan magelang tahun 2009. J Kebidanan. 2009;39-44.

24. Saryono; Sejati W. Sindrom premenstruasi. Yogyakarta: Nuha Medika; 2009. 17-24, 2732,47-48 p.

25. Ramadani M. Premenstrual syndrome (PMS). J Kesehat Masy. 2012;7(1):167-73.

26. Paath, Erna Francin; Heryati; Rumdasih Y. Gizi dalam kesehatan reproduksi. Jakarta: EGC; 2004. 48, 110-114. p.

27. Pratiwi AM. Aktivitas olahraga dengan kejadian sindrom premenstruasi pada anggota perempuan UKM INKAI UNS. Jnki. 2016;2(2):76-80.

28. Guyton, AC; Hall J. Buku ajar fisiologi kedokteran. 11th ed. Jakarta: EGC; 2008. 